\title{
Grid integration of PMSG based wind energy conversion with battery storage system
}

\author{
Venkatachalam K M, V. Saravanan
}

Department of Electrical and Electronics Engineering, Arunai Engineering College, Anna University, Tamil Nadu, India

\begin{tabular}{|c|c|}
\hline Article Info & ABSTRACT \\
\hline Article history: & In this paper, the design and implementation of a permanent magnet \\
\hline Received Apr 22, 2020 & $\begin{array}{l}\text { synchronous generator (PMSG) based wind energy conversion system and } \\
\text { battery bank storages are connected to utility grid. It has phase locked loop }\end{array}$ \\
\hline Revised Jun 7, 2020 & (PLL) control strategy as it provides for control single-phase grid connected \\
\hline Accepted Oct 16, 2020 & $\begin{array}{l}\text { inverter with constant dc-link voltage. The dc-link is interfaced to a } \\
\text { permanent magnet synchronous generator through diode bridge rectifier }\end{array}$ \\
\hline Keywords: & $\begin{array}{l}\text { (DBR) with dc-dc boost converter, battery bank and single phase voltage } \\
\text { source inverter (VSI). The dc-link voltage is maintained constant value of }\end{array}$ \\
\hline Battery hank & $48 \mathrm{~V}$ by controlling dc-dc converter with help of perturb and observe ( $\mathrm{P} \& \mathrm{O})$ \\
\hline DC-DC converter & algorithm based maximum power point tracker (MPPT). The VSI output \\
\hline PMSG & voltage and frequency values are controlled based on grid parameters using \\
\hline Single phase VSI & $\begin{array}{l}\text { this grid connected system is simulated and performances are analyzed } \\
\text { through MATLAB software. The prototype experimental results are verified } \\
\text { through } 1 \mathrm{~kW} \text { PMSG, } 48 \mathrm{~V} \text { battery bank with single phase grid connected } \\
\text { system. }\end{array}$ \\
\hline
\end{tabular}

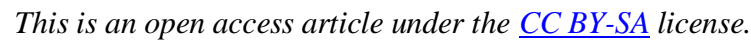

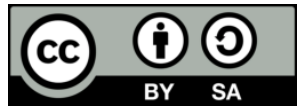

\section{Corresponding Author:}

Venkatachalam K M

Faculty of Electrical Engineering

Arunai Engineering College, Anna University

Tiruvannamalai 606 603, Tamil Nadu, India

Email:kmvpeee@gmail.com

\section{INTRODUCTION}

The power demands are increasing due to demand of the conventional fuel sources. Renewable energy source based power generations are needed to distribute and compensate the requirement with uninterrupted continuous power supply. Wind energy electrical conversion system is a most popular in overall renewable energy sources. In this wind energy conversion system is operating the non-linear characteristics due to continuous variation of wind velocity [1-5]. Various techniques are implemented for extracting maximum power from wind energy conversion system and fed to the utility grid. In last few years permanent magnet synchronous generators (PMSG) are used in wind energy conversion system because it is a direct driven fully controlled machine [6-11]. The maximum power extracted from PMSG wind system with help of perturb and observe (P\&O) method based maximum power point tracker (MPPT) [12-18].

The variable ac three phase electrical output of the PMSG is converted to dc electric power by using three phase diode bridge rectifier (DBR) and it's consisting of six diodes. In this DBR dc output is boost and regulated output power is fed to the inverter with help of dc-dc boost converter [19-21]. The dc-link voltage is a reference value for MPPT and compare with actual value of the PMSG output power, this error value is given to the PI controller. In this PI controller can vary dc-dc converter pulse signal based on error values for maintain constant dc-link voltage. The inverter is convert dc power into ac power and connected to the grid and it's maintaining constant grid voltage with required constant grid frequency. The VSI output voltage is 
measured by phase locked loop (PLL) and converted to direct axis and quadrature axis (dq0) [22]. The dq axis conversion voltage and reference voltage is compared and error value is given to the VSI driver circuits. The single phase voltage source inverter (VSI) is controlled by many driver control technique like sinusoidal pulse width modulation (SPWM), space vector modulation technique. The most suitable an easy control technique is a SPWM method to drive the voltage source inverter [23-24]. In this proposed grid connected system consist of (i) PMSG based WECs, (ii) diode bridge rectifier (DBR), (iii) dc-dc boost converter, (iv) single phase voltage source inverter (VSI), maximum power point tracker (MPPT), battery bank storage system.

\section{GRID CONNECTED SYSTEM DESCRIPTION}

The proposed grid connected system as shown in Figure 1. It is comprised of permanent magnet synchronous generator based (PMSG) WECs operating with maximum power point tracker (MPPT), battery is using for energy storage, voltage source inverter (VSI), LC filter and single phase utility grid. The WECs is designed at maximum power rating of $1 \mathrm{~kW}$. The MPPT is extract maximum power from PMSG and to control dc-dc converter for constant voltage. The battery bank designed the combination of series and parallel connection of battery with respect to required voltage and current. The battery bank is designed with 8 battery of $12 \mathrm{~V}, 100 \mathrm{Ah}$. A constant DC bus voltage is maintained by bidirectional converter and it power transfer to the VSI. The VSI is fed the power from PMSG wind conversion system with battery bank. The VSI single phase output is fed to the utility grid through LC filter. It is used for pure AC power feed to the grid without any harmonic disturbances. The constant voltage, current and frequency are fed to the utility grid. In this system configuration helps extract the maximum power from WECs at varying wind velocity, load and power fed to the utility grid. The system ensure constant power feed to the grid that excess WECs energy is stored to the battery bank which is useful for peak load demand and to maintain constant output power during fluctuation of wind velocity and load.

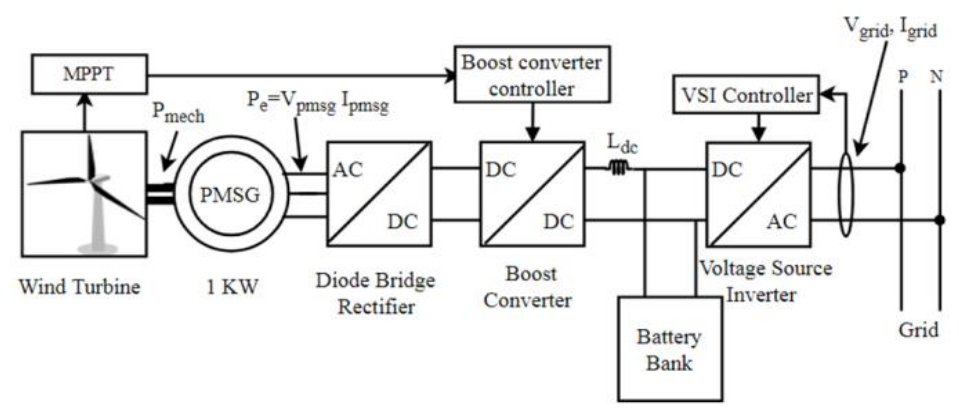

Figure 1. Block schematic of the proposed system

\section{PROPOSED SYSTEM DESIGN AND MODELING}

The proposed system design of single phase two stage grid connected WECs system is described in this section. The design of grid connected system is based on utility grid standard voltage and frequency. The switching frequency of the inverter is higher than the line frequency.

\subsection{Wind turbine model}

The mechanical power output captured from the wind turbine is given by [10, 25].

$$
P_{w}=\frac{1}{2} \rho A C_{p}(\beta, \lambda) v_{w}^{3}
$$

where $\rho$ is the density of the air $\left(\mathrm{kg} / \mathrm{m}^{3}\right), A$ is the area of the rotor blade, $\mathrm{C}_{\mathrm{p}}$ is a power co-efficient of the wind turbine, $\beta$ is the rotor blades pitch angle, $V_{\omega}$ is a wind velocity $(\mathrm{m} / \mathrm{s}), \lambda$ is a tip speed ratio and it can be written as:

$$
\lambda=\frac{R \omega_{m}}{v_{w}}
$$


where $\mathrm{R}$ is the radius of blade in meter, $\omega_{\mathrm{m}}$ is the angular speed of the rotor ( $\left.\mathrm{rad} / \mathrm{sec}\right)$. The power co-efficient of the wind turbine $\mathrm{Cp}$ is derived based on the characteristics of wind turbine.

$$
C_{p}(\beta, \lambda)=\sum_{i=0}^{4} \sum_{j=0}^{4} a_{i j} \beta^{i} \lambda^{j}
$$

Figure 2 represents the $\mathrm{Cp}$ vs $\lambda$ curve, the maximum output power captured from the wind turbine at constant wind speed irrespective of wind velocity. Hence the same wind turbine maximum output power delivered at different wind velocity corresponding to maximum power point tracker. In a wind turbine direct drive-train system are classified as a single-mass and two-mass depends on the application. In variable speed wind application, the limited wind speed variation, single-mass drive system is sufficient because the shaft oscillation is very less and easy control the grid connected system in order to active power control. The single-mass drive mathematical relation is given in (1) [10].

$$
T_{m}=J_{e q} \frac{d \omega_{m}}{d t}+B \omega_{m}+T_{e}
$$

where $\mathrm{Tm}$ is the mechanical torque, Jeq is the total equivalent inertia of the rotor of wind turbine and generator, $\mathrm{B}$ is the damping co-efficient, $\omega_{\mathrm{m}}$ is the angular speed of the rotor $(\mathrm{rad} / \mathrm{sec})$.

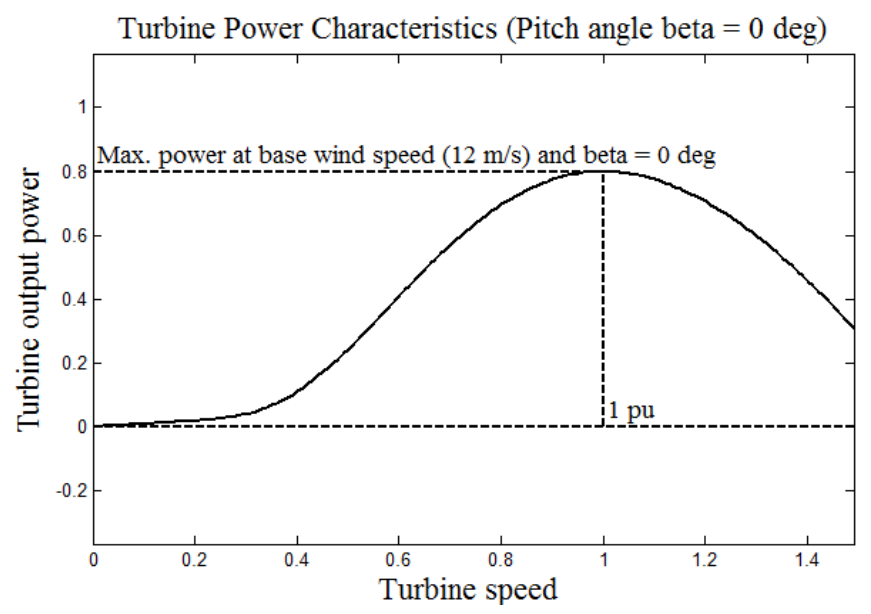

Figure 2. Wind turbine output power vs speed

while the wind speed variation is more, the shaft oscillation and grid connected systems are heavily disturbed. In order reduce the shaft oscillation two-mass drive systems are used as represented in Figure 3. The two-mass drive mathematical relation given in (2).

$$
\frac{d \omega_{t}}{d t}=\frac{1}{J_{t}}\left(T_{t}-T_{d t}-T_{a t}-T_{s}\right)
$$

where $\omega_{\mathrm{t}}$ is the angular speed of the wind turbine, $\mathrm{Jt}$ is the moment inertia of the wind turbine, Tt is the mechanical torque WT bearing, Tdt is the turbine resistant torque in turbine, Tat is the turbine resistant torque in blades, Ts is the torsional stiffness torque.

$$
\frac{d \omega_{g}}{d t}=\frac{1}{J_{g}}\left(T_{t s}-T_{d g}-T_{a g}-T_{g}\right)
$$

where $\omega_{\mathrm{g}}$ is the angular speed of the generator, $\mathrm{Jg}$ is the moment inertia of the generator, Tdg is the turbine resistant torque in generator bearings, Tag is the turbine resistant torque in generator, Tag is the turbine resistant torque in generator, $\mathrm{Tg}$ is the generator electrical torque. 


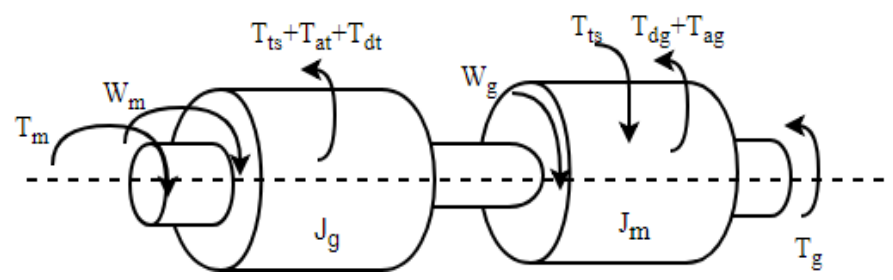

Figure 3. Two-mass drive systems

\subsection{PMSG model}

The PMSG model is represented in the synchronous reference (Vd, Vq) frame [6].

$$
\begin{aligned}
& V_{d}=R_{s} i_{d}+\lambda_{d}-\omega_{e} \psi_{q} \\
& V_{q}=R_{s} i_{q}+\lambda_{d}+\omega_{e} \psi_{d}
\end{aligned}
$$

where $\mathrm{V}_{\mathrm{d}}, \mathrm{V}_{\mathrm{q}}$ and id, iq are the dq stator voltage and current components, respectively. $\psi_{\mathrm{d}}, \psi_{\mathrm{q}}$ are the stator flux linkage, Rs is the stator resistance, $\omega_{\mathrm{e}}$ is the angular speed of the rotor. The PMSG developed electromagnetic torque is:

$$
\begin{aligned}
& T_{e}=1.5 P\left(\lambda_{d} i_{q}-\psi_{d} i_{d}\right) \\
& T_{e}=1.5 P\left(\psi_{p m} i_{q}+\left(L_{d}-L_{q}\right)-i_{d} i_{q}\right)
\end{aligned}
$$

where $\mathrm{P}$ is a number of pole pairs, $\mathrm{L}_{\mathrm{d}}, \mathrm{L}_{\mathrm{q}}$ are the inductance of the stator reference frame, $\psi_{\mathrm{pm}}$ is a rotor magnetic flux linkage.

\subsection{Design of diode bridge rectifier (DBR) and boost converter}

The three phase diode bridge rectifier (DBR) is consist of three set of diode. It is covert three phase variable ac electrical supply into variable dc electrical supply. The output voltage of the DBR is based on speed of the wind turbine. The diode bridge rectifier (DBR) output is fed to dc-dc boost converter, which are boosting the DBR voltage and maintain constant output dc voltage. In excremental setup, the required input voltage to store energy in the battery is $48 \mathrm{~V}$ constant dc supply. In the DBR output voltage is lower and variable than the battery input voltage depends on solar radiation. The relation between the DBR output voltages $\left(\mathrm{V}_{\text {wind }}\right)$, boost converter output voltage $\left(\mathrm{V}_{\mathrm{dc}}\right)$ is defined as duty cycle (D) of boost converter.

$$
D=1-\left(\frac{V_{\text {wind }}}{V_{d c}}\right)
$$

The required input inductor $\left(\mathrm{L}_{\text {in }}\right)$ value to maintain the continuous conduction mode $(\mathrm{CCM})$ operation is:

$$
L_{i}=\frac{V_{\text {wind }}}{\left(\Delta \boldsymbol{I}_{\text {wind }}\right)}=\frac{V_{\text {wind }}^{2}}{(0.1) P_{\text {wind }}}\left(1-\frac{V_{\text {wind }}}{V_{d c}}\right)
$$

where $I_{\text {wind }}$ is the minimum rippled input current, $T$ is the time of switching cycle, $P_{\text {wind }}$ is the maximum output power from Solar PV array.

\subsection{Design of DC-link capacitor and inductor}

The DC-link capacitor is transfer power from input to output with control manner. The DC-link capacitor value is depends on the DC bus voltage as:

$$
C_{d}=\frac{P_{d c} / V_{d c}}{2 \times \omega \times \Delta V_{d c}}
$$


where $V_{d c}$ is a minimum allowable ripple in the DC-link voltage, $P_{d c}$ is a dc power, $I_{d c}$ is a DC current, $\omega$ is a line frequency.

The inductor is coupling element between the boost converter and voltage source inverter (VSI). It is used for elimination of high frequency switching harmonics. The inductor design calculation as:

$$
L_{f}=\frac{m \times V_{d c}}{6 \times f_{s} \times h \times \Delta \boldsymbol{i}_{c}}
$$

where $\mathrm{f}_{\mathrm{s}}$ is a switching frequency, Vic is a ripple current, $\mathrm{m}$ and $\mathrm{h}$ are the constant parameters.

\subsection{Design of bidirectional converter}

The bidirectional converter is to control the DC output voltage $\left(\mathrm{V}_{\mathrm{dc}}\right)$ and battery current $\left(\mathrm{I}_{\mathrm{b}}\right)$, It is designed for the power rating of $3 \mathrm{~kW}$ and operating frequency is $20 \mathrm{kHz}$. The bidirectional converter is connected between the battery and DC bus, is operated on two modes. While battery is charging the converter can operate buck operation and while battery is discharging the converter can operate boost operation. The bidirectional converter operating mode is desired by the inductor and duty cycle of the converter is as:

$$
\begin{aligned}
& \text { Duty cycle } \quad(D)=\frac{V_{b}}{V_{d c}} \\
& L_{d c}=\frac{D\left(V_{d c}-V_{b}\right)}{f_{s} I_{L}} \quad \text { (Buck mode) } \\
& L_{d c}=\frac{D V_{b}}{f_{\Delta} I_{L}} \quad \text { (Boost mode) }
\end{aligned}
$$

where $V_{b}$ is a battery voltage, $V_{d c}$ is DC bus voltage, $I_{L}$ is a ripple current in the battery, $f_{s}$ is switching frequency.

\section{PROPOSED SYSTEM CONTROL TECHNIQUE}

The control of the dc-dc boost converter output impedance is matches to the varying DBR impedance for get maximum power. The bidirectional converter is control the DC-link voltage (Vdc), battery current (Ib) is a reference value of the converter. The voltage source inverter (VSI) is controlled by the PI controller based on availability of wind power or battery power. The MPPT controller, boost converter controller, and voltage source inverter controller are explained in the following sections.

\subsection{Maximum power point tracker (MPPT) controller}

The MPPT is tracks the maximum power from PMSG wind energy conversion system using simple perturb and observe method by sensing the dc-link current. To measured and comparing the previous dc-link current Idc (k-1) and present dc-link current Idc (k). If the present dc link current Idc (k) is more than the previous dc-link current Idc $(\mathrm{k}-1)$, the perturbation is increases up to maximum power point. If the present dc link current Idc $(\mathrm{k})$ is less than the previous dc-link current Idc $(\mathrm{k}-1)$, the perturbation has to be decrease. The DC bus current is positive when the PMSG power available in excess to battery and fed to grid. When the wind power is not sufficient feet to grid, the deficit power is fed from battery by DC bus current is negative.

\subsection{Voltage control of boost converter}

The dc-link voltage $\left(\mathrm{V}_{\mathrm{dc}}\right.$-link) is compared with reference dc voltage of $200 \mathrm{~V}$ and fed to PI controller. The error signal of the PI controller is compared with carrier waveform of $20 \mathrm{kHz}$ to produce the pulse width modulation (PWM) gate signal is control the boost converter switches as shown in Figure 2. The PI controller parameters $\left(\mathrm{K}_{\mathrm{p}}, \mathrm{K}_{\mathrm{i}}\right)$ values are set by manual tuning method. The $\mathrm{K}_{\mathrm{p}}$ and $\mathrm{K}_{\mathrm{i}}$ values are depends on the system behavior and response. The $\mathrm{K}_{\mathrm{p}}$ and $\mathrm{K}_{\mathrm{i}}$ values are set as 0.015 and 0.4 in PI controller by using this method. 


\subsection{Grid synchronization}

The single phase grid has voltage is $415 \mathrm{~V}_{(\mathrm{rms})}$ and frequency is $50 \mathrm{~Hz}$. The voltage source inverter voltage magnitude and frequency should match with the grid voltage magnitude and frequency. The grid voltage and frequency are measured using phase-locked loop (PLL) and it's compared with the VSI voltage and frequency and the error is reduced by using PI controller. The PI controller is forced to matches the VSI and grid using Sinusoidal pulse width modulation (SPWM) with reference signal. The voltage source inverter equivalent circuit and control circuit as shown in Figures 4(a) and (b).

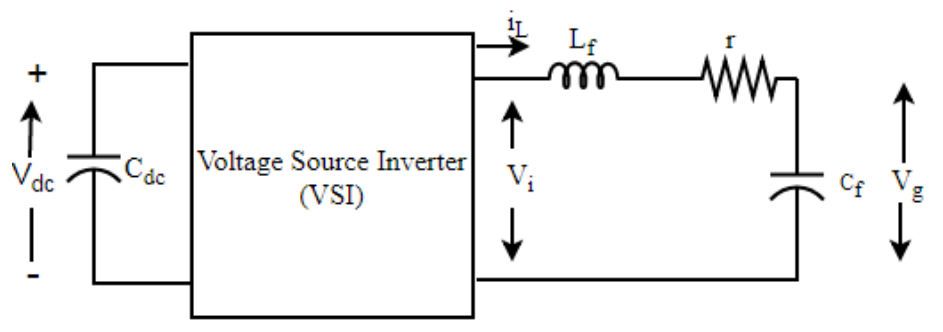

(a)

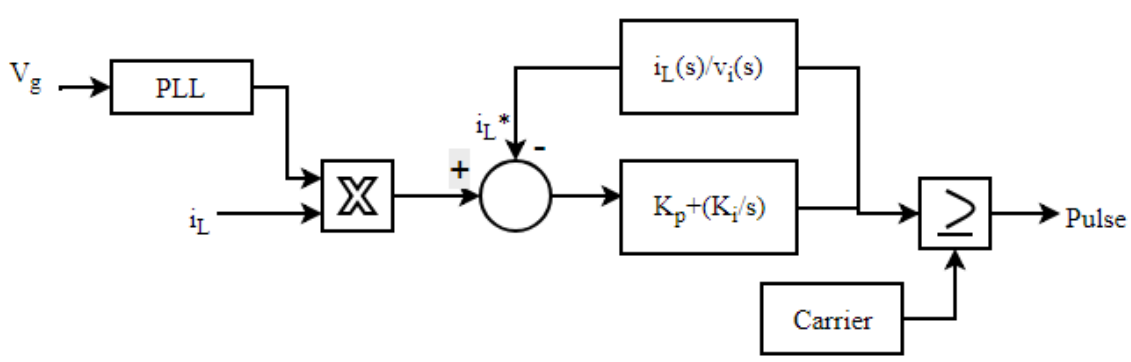

(b)

Figure 4. The voltage source inverter, (a) Equivalent circuit of the VSI, (b) Control circuit of the VSI

The grid voltage is fed to phase-locked loop (PLL) and its output current is to be maintaining constant magnitude and it is reference for this control circuit. PI controller parameters $\mathrm{K}_{\mathrm{p}}$ is 0.25 and $\mathrm{K}_{\mathrm{i}}$ is 80.836 are obtained. The PI controller voltage control loop transfers function as:

$$
\frac{i_{L}(s)}{V_{i}(s)}=\frac{1}{\left(L_{f} s+r\right)}
$$

where $\mathrm{i}_{\mathrm{L}}$ is a current through inductor, $\mathrm{V}_{\mathrm{i}}$ is a VSI output voltage, $\mathrm{r}$ is a resistance.

\section{RESULTS AND DISCUSSION}

The proposed single phase grid connected system is validated on a simulation at steady state condition of wind speed is $12 \mathrm{~m} / \mathrm{s}$. The implemented perturb and observe (P\&O) algorithm based maximum power point tracker (MPPT) for wind generator is track the maximum power and output voltage is compared with the dc-link voltage. The dc-dc converter and grid side inverter is effectively transferred the renewable energy power generation to utility grid, which is validated from the simulation results as shown in Figures 5 (a) and (b). It shows the simulation results of single phase inverter output voltage and current under constant wind speed of $12 \mathrm{~m} / \mathrm{s}$ with corresponding value of total harmonic distraction (THD) waveforms. The experimental hardware prototype implemented for single phase grid connected system. The maximum power tracked from the $1 \mathrm{~kW}$ PMSG wind generator using MPPT, its convert and regulated to dc constant $48 \mathrm{~V}$ dc supply with help of wind charge controller. The charge controller is interfaced to $48 \mathrm{~V}, 800 \mathrm{Ah}$ battery bank and $1.5 \mathrm{~kW}$ single phase grid tie inverter. 

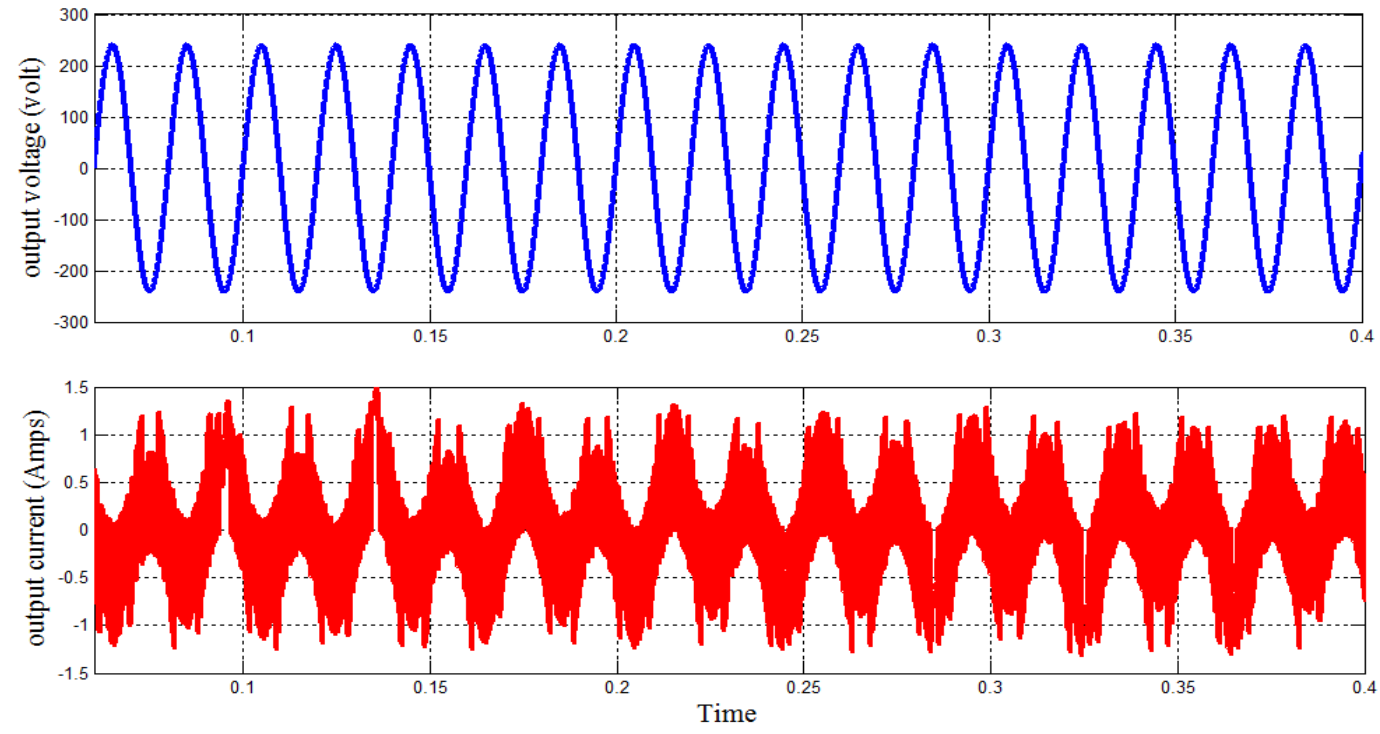

(a)
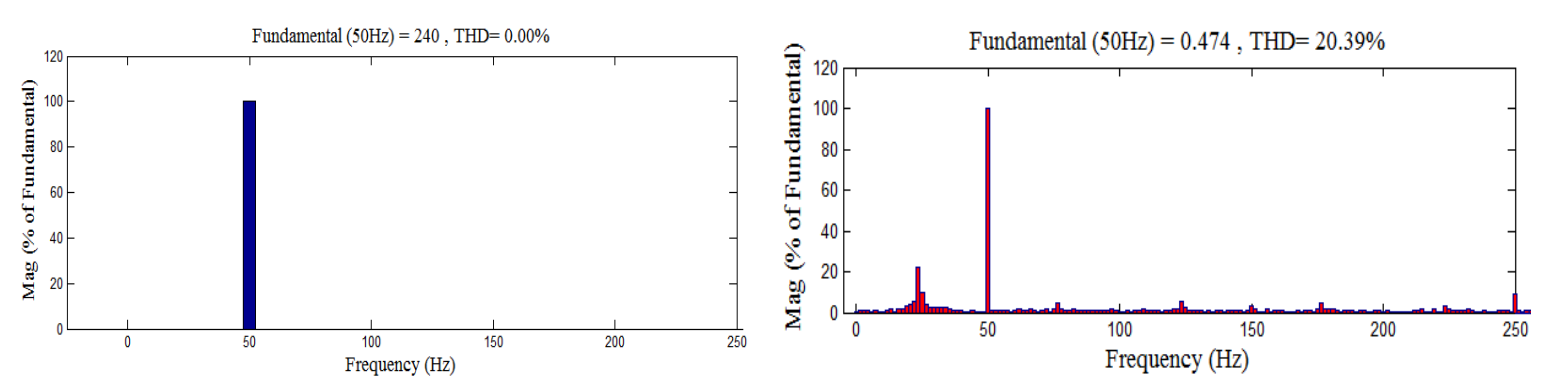

(b)

Figure 5. Simulation results of, (a) Output voltage and current of VSI, (b) Voltage and current THD of VSI

When the availability of wind speed is more the generated electrical power is fed to grid or to battery for charging, wind speed is not reached to above cut-in speed the PMSG cannot generate the electrical power. In this situation the power flows from grid to battery bank using bidirectional converter. The experimental result of PMSG wind generator three phase output voltage and single phase inverter voltage, current, and total harmonic distraction (THD) at various load condition are measured by power quality analyzer as shown in Figures 6-9. The proposed system specifications are provided in Table 1.
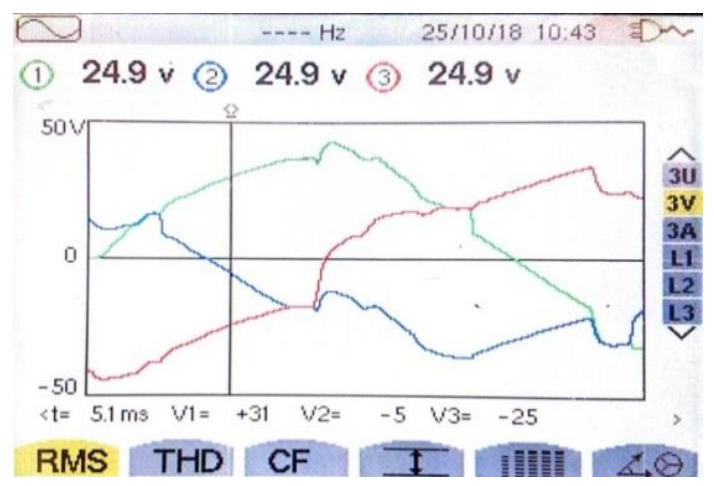

Figure 6. PMSG wind generator output voltage 


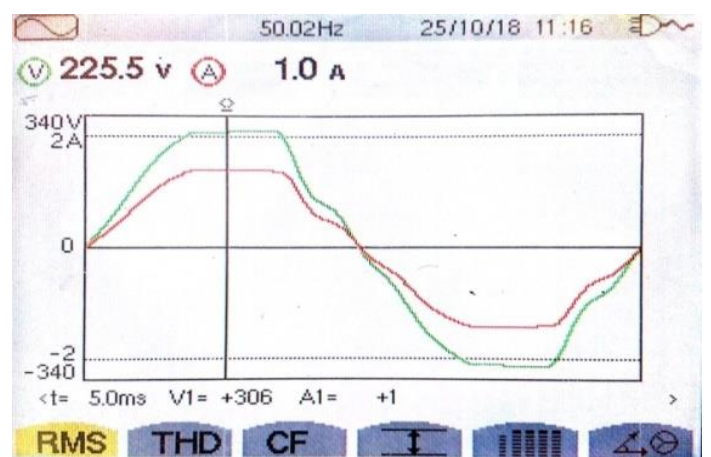

(a)

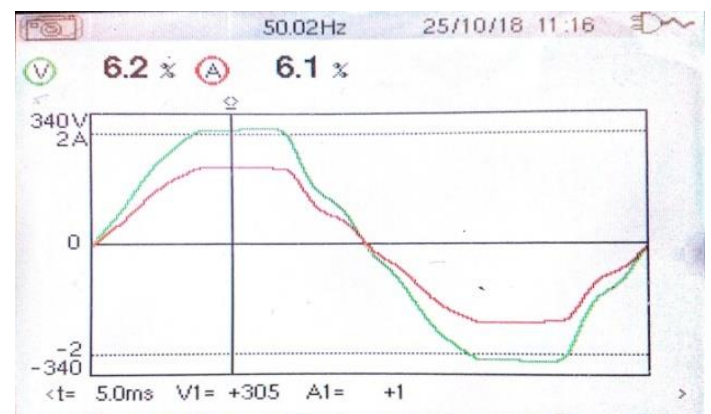

RMS THD CF I I

Figure 7. Inverter voltage, (a) Current at $260 \mathrm{~W}$ lamp load, (b) THD at $260 \mathrm{~W}$ lamp load

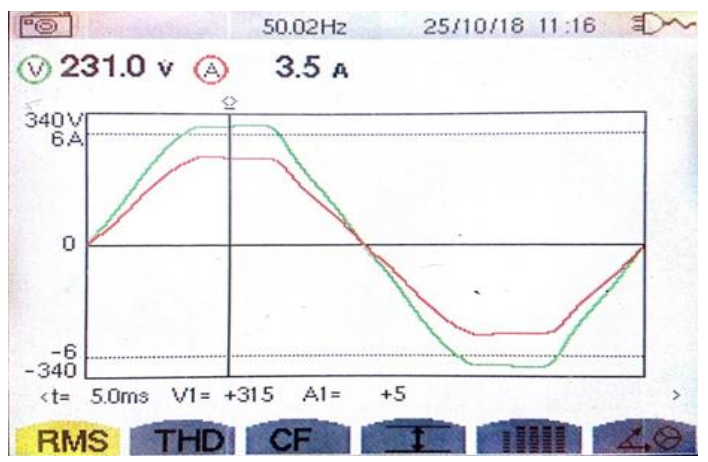

(a)

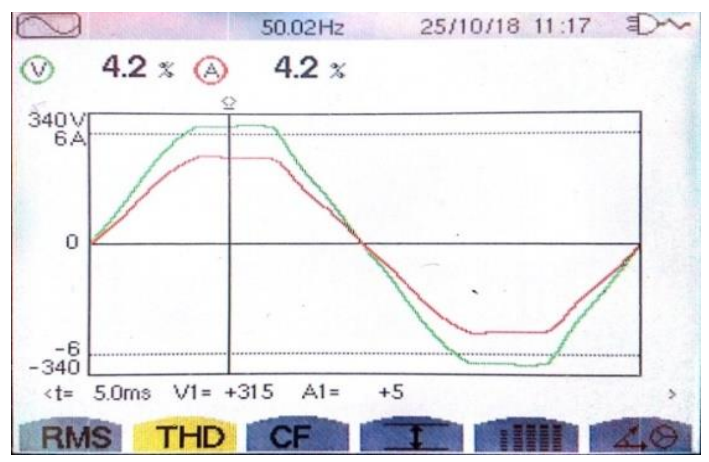

(b)

Figure 8. Inverter voltage, (a) Current at $820 \mathrm{~W}$ lamp load, (b) THD at $820 \mathrm{~W}$ lamp load

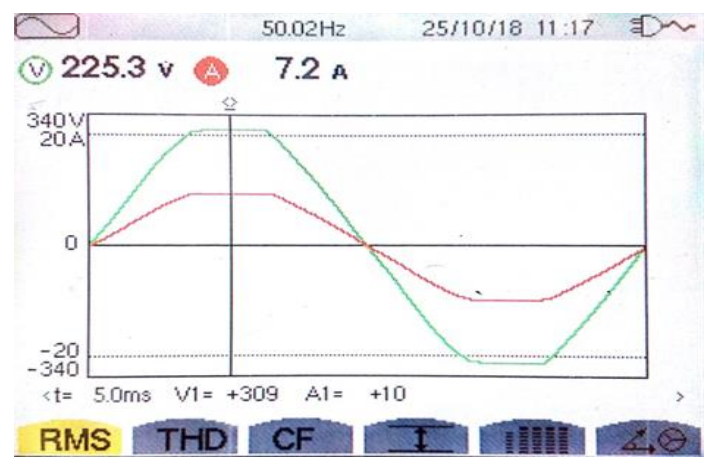

(a)

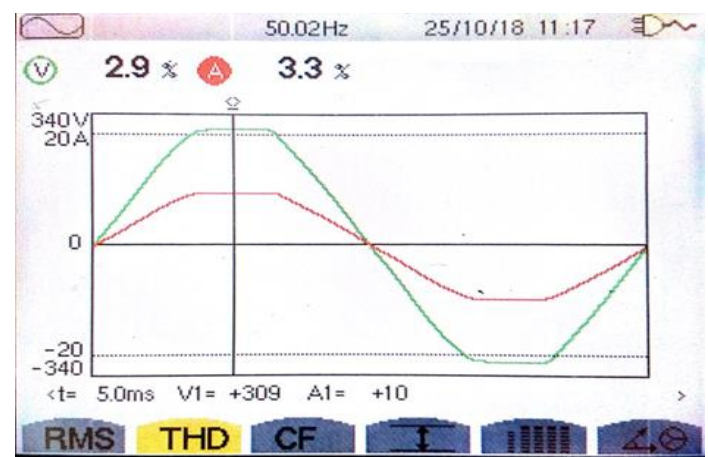

(b)

Figure 9. Inverter voltage, (a) Current at $1680 \mathrm{~W}$ lamp load, (b) THD at $1680 \mathrm{~W}$ lamp load

\begin{tabular}{|c|c|c|}
\hline S.no & Specifications of WECs & \\
\hline 1 & PMSG rating & $1 \mathrm{~kW}$ \\
\hline 2 & Number of blades & 3 \\
\hline 3 & Rotor diameter & $2.72 \mathrm{M}$ \\
\hline 4 & Available wind speed & 4 to $6 \mathrm{~m} / \mathrm{s}$ \\
\hline 6 & Wind charge controller & $48 \mathrm{~V}$ \\
\hline 7 & Battery bank & $48 \mathrm{~V}, 800 \mathrm{Ah}$ \\
\hline 8 & Grid-tie inverter & $1.5 \mathrm{~kW}$ \\
\hline
\end{tabular}




\section{CONCLUSION}

This paper presented a PMSG based wind energy conversion system and battery bank interfaced through a common dc-link. The dc voltage is regulated and maintained constant to an MPPT of PMSG through dc-dc converter. The wind charge controller duty cycle variation is depends on the wind generator output power, the system extract maximum power from PMSG and transfer to the utility grid through grid side inverter at variable wind velocity. The grid side inverter is controlled using phase locked loop technical with PI controller. The proposed grid connected wind energy conversion system performances are validated through MATLAB SIMULINK and prototype hardware experimental setup.

\section{ACKNOWLEDGEMENTS}

This work was supported by Wind Energy Division, Ministry of New \& Renewable Energy, Government of India under grant (IFD Dy. No. 1429 dated 04/11/2016, Demand No. 61/69, Budget Head: 2810.00.104.04.05.31/35).

\section{REFERENCES}

[1] P. Shanthi, G. Uma and M. S. Keerthana, "Effective power transfer scheme for a grid connected hybrid wind/photovoltaic system," in IET Renewable Power Generation, vol. 11, no. 7, pp. 1005-1017, 2017, doi: 10.1049/iet-rpg.2016.0592.

[2] A. Merabet, K. Tawfique Ahmed, H. Ibrahim, R. Beguenane and A. M. Y. M. Ghias, "Energy Management and Control System for Laboratory Scale Microgrid Based Wind-PV-Battery," in IEEE Transactions on Sustainable Energy, vol. 8, no. 1, pp. 145-154, Jan. 2017, doi: 10.1109/TSTE.2016.2587828.

[3] M. Gholami, S. H. Fathi, J. Milimonfared, Z. Chen and F. Deng, "A new strategy based on hybrid battery-wind power system for wind power dispatching," in IET Generation, Transmission \& Distribution, vol. 12, no. 1, pp. 160-169, 2018, doi: 10.1049/iet-gtd.2017.0454.

[4] X. Xu, M. Bishop, D. G. Oikarinen and C. Hao, "Application and modeling of battery energy storage in power systems," in CSEE Journal of Power and Energy Systems, vol. 2, no. 3, pp. 82-90, Sept. 2016, doi: 10.17775/CSEEJPES.2016.00039.

[5] K. Basaran, N. S. Cetin and S. Borekci, "Energy management for on-grid and off-grid wind/PV and battery hybrid systems," in IET Renewable Power Generation, vol. 11, no. 5, pp. 642-649, 2017, doi: 10.1049/iet-rpg.2016.0545.

[6] P. Xing, L. Fu, G. Wang, Y. Wang and Y. Zhang, "A compositive control method of low-voltage ride through for PMSG-based wind turbine generator system," in IET Generation, Transmission \& Distribution, vol. 12, no. 1, pp. 117-125, 2018, doi: 10.1049/iet-gtd.2017.0270.

[7] B. Mangu, S. Akshatha, D. Suryanarayana and B. G. Fernandes, "Grid-Connected PV-Wind-Battery-Based MultiInput Transformer-Coupled Bidirectional DC-DC Converter for Household Applications," in IEEE Journal of Emerging and Selected Topics in Power Electronics, vol. 4, no. 3, pp. 1086-1095, Sept. 2016, doi: 10.1109/JESTPE.2016.2544789.

[8] N. Saxena, B. Singh and A. L. Vyas, "Single-phase solar PV system with battery and exchange of power in gridconnected and standalone modes," in IET Renewable Power Generation, vol. 11, no. 2, pp. 325-333, 2017, doi: 10.1049/iet-rpg.2016.0143.

[9] C. M. Jenisha, N. Ammasaigounden, N. Kumaresan and K. BhagyaSri, "Power electronic interface with de-coupled control for wind-driven PMSG feeding utility grid and DC load," in IET Power Electronics, vol. 11, no. 2, pp. 329338, 2018, doi: 10.1049/iet-pel.2017.0347.

[10] Hong-Woo Kim, Sung-Soo Kim and Hee-Sang Ko, "Modeling and control of PMSG-based variable-speed wind turbine, "Electric Power Systems Research, 2010, vol. 80, no. 1, pp. 46-52, 2010.

[11] Youssef Barradi, Khalida Zazi, Malika Zazi and Naoufel Khaldi, "Control of PMSG based variable speed wind energy conversion system connected to the grid with PI and ADRC approach," International Journal of Power Electronics and Drive system, vol. 11, no. 2, pp. 953-968, 2020.

[12] M. Kesraoui, N. Korichi and A. Belkadi, "Maximum power point tracker for wind energy conversion system, "Renewable Energy, vol. 36, no. 10, pp. 2655-2662, 2011.

[13] N. Mendis, K. M. Muttaqi, S. Sayeef and S. Perera, "Standalone Operation of Wind Turbine-Based Variable Speed Generators With Maximum Power Extraction Capability," in IEEE Transactions on Energy Conversion, vol. 27, no. 4, pp. 822-834, Dec. 2012, doi: 10.1109/TEC.2012.2206594.

[14] M. M. R. Singaravel and S. A. Daniel, "MPPT With Single DC-DC Converter and Inverter for Grid-Connected Hybrid Wind-Driven PMSG-PV System," in IEEE Transactions on Industrial Electronics, vol. 62, no. 8, pp. 48494857, Aug. 2015, doi: 10.1109/TIE.2015.2399277.

[15] R. M. Linus and P. Damodharan, "Maximum power point tracking method using a modified perturb and observe algorithm for grid connected wind energy conversion systems," in IET Renewable Power Generation, vol. 9, no. 6, pp. 682-689, 2015, doi: 10.1049/iet-rpg.2014.0070.

[16] M. Rezkallah, A. Hamadi, A. Chandra and B. Singh, "Design and Implementation of Active Power Control With Improved P\&O Method for Wind-PV-Battery-Based Standalone Generation System," in IEEE Transactions on Industrial Electronics, vol. 65, no. 7, pp. 5590-5600, July 2018, doi: 10.1109/TIE.2017.2777404. 
[17] Bouchaib Rached, Mustapha Elharoussi and Elhassane Abdelmounim, "Design and investigations of MPPT strategies for a wind energy conversion system based on doubly fed induction generator," International Journal of Electrical and Computer Engineering, vol. 10, no. 5, pp. 4770-4781, 2020.

[18] K. M. Venkatachalam and V.Saravanan, "Performance evaluation and load demand management of grid connected hybrid wind-solar-battery system," International Journal of Applied Power Engineering, 2020, vol. 9, no. 3, pp. 223-244, 2020.

[19] F. Deng, D. Liu, Z. Chen and P. Su, "Control strategy of wind turbine based on permanent magnet synchronous generator and energy storage for stand-alone systems," in Chinese Journal of Electrical Engineering, vol. 3, no. 1, pp. 51-62, 2017, doi: 10.23919/CJEE.2017.7961322.

[20] Tiara R.S. de Freitas, Paulo J.M. Menegáz and Domingos S.L. Simonetti, "Rectifier topologies for permanent magnet synchronous generator on wind energy conversion systems: A review, "Renewable and Sustainable Energy Reviews, vol. 54, pp. 1334-1344, 2016.

[21] C. S. Purohit, Geetha M, P. Sanjeevikumar, P. K. Maroti, S. Swami and V. K. Ramachandaramurthy, "Performance analysis of DC/DCbidirectional converter with sliding mode and pi controller, "International Journal of Power Electronics and Drive System, vol. 10, no. 1, pp. 357-365, 2019.

[22] S. M. Tripathi, A. N. Tiwari, Deependra Singh, "Grid-integrated permanent magnet synchronous generator based wind energy conversion systems: A technology review, "Renewable and Sustainable Energy Reviews, vol. 51, pp. 1288-1305, 2015.

[23] A. S. Bubshait, A. Mortezaei, M. G. Simões and T. D. C. Busarello, "Power Quality Enhancement for a Grid Connected Wind Turbine Energy System," in IEEE Transactions on Industry Applications, vol. 53, no. 3, pp. 24952505, May-June 2017, doi: 10.1109/TIA.2017.2657482.

[24] B. K. Ramasamy, A. Palaniappan and S. M. Yakoh, "Direct-drive low-speed wind energy conversion system incorporating axial-type permanent magnet generator and Z-source inverter with sensorless maximum power point tracking controller," in IET Renewable Power Generation, vol. 7, no. 3, pp. 284-295, May 2013, doi: 10.1049/ietrpg.2012.0248.

[25] S. Mishra, I. Hussain, G. Pathak and B. Singh, "dPLL-based control of a hybrid wind-solar grid connected inverter in the distribution system," in IET Power Electronics, vol. 11, no. 5, pp. 952-960, 2018, doi: 10.1049/ietpel.2017.0491.

\section{BIOGRAPHIES OF AUTHORS}
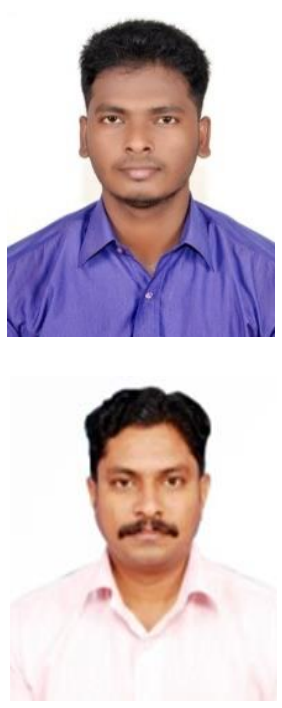

Mr. Venkatachalam K M received bachelor degree in Electrical and Electronics Engineering from Anna University, Chennai in 2014. He has received master degree in Electrical Drives and Control from Pondicherry University, Puducherry in 2016. Currently he is pursuing Ph.D. degree in Electrical Engineering, Anna University, Chennai. His area of research includes renewable energy, inverters and micro-grid. He published 10 papers in conferences and journals.

Dr. V. Saravanan working as professor in Department of Electrical \& Electronics Engineering, Arunai Engineering College, Tiruvannamalai, Tamil Nadu, India and has been carrying out R \& $\mathrm{D}$ activities sponsored by various agencies of Government of India in the area of renewable energy systems. He has teaching/industrial experience of about 15 years. His research interests include solar photovoltaic power systems, distributed renewable energy systems, smart/microgrid. He published more than 70 research papers in journals, conferences and exhibitions. 